\title{
Acute pesticide poisoning: a proposed classification tool
}

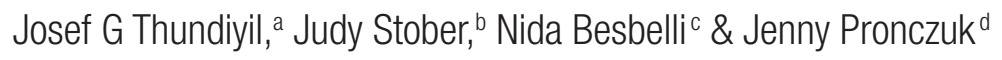

\begin{abstract}
Cases of acute pesticide poisoning (APP) account for significant morbidity and mortality worldwide. Developing countries are particularly susceptible due to poorer regulation, lack of surveillance systems, less enforcement, lack of training and inadequate access to information systems. Previous research has demonstrated wide variability in incidence rates for APP. This is possibly due to inconsistent reporting methodology and exclusion of occupational and non-intentional poisonings. The purpose of this document is to create a standard case definition to facilitate the identification and diagnosis of all causes of APP, especially at the field level, rural clinics and primary health-care systems. This document is a synthesis of existing literature and case definitions that have been previously proposed by other authors around the world. It provides a standardized case definition and classification scheme for APP into categories of probable, possible and unlikely/unknown cases. Its use is intended to be applicable worldwide to contribute to identification of the scope of existing problems and thus promote action for improved management and prevention. By enabling a field diagnosis for APP, this standardized case definition may facilitate immediate medical management of pesticide poisoning and aid in estimating its incidence.
\end{abstract}

Bulletin of the World Health Organization 2008;86:205-209.

Une traduction en français de ce résumé figure à la fin de l'article. Al final del artículo se facilita una traducción al español. التزجمة العربية لهذه الخلاصة في نهاية النص الكامل لهذه المقالة.

\section{Background}

Cases of acute pesticide poisoning (APP) account for significant morbidity and mortality worldwide, especially in developing countries. ${ }^{1,2}$ There are no reliable estimates as to how many people per year suffer from pesticide-related health effects. This is due to several reasons including a lack of standardized case definition. The purpose of this document is to create a standard case definition to facilitate the identification and diagnosis of APP, especially at the field level, in rural clinics and primary health-care systems. The case definition is inclusive of all circumstances of poisoning including suicide, homicide, non-intentional (accidental exposure) and occupational.

Studies in developed countries have demonstrated the annual incidence rates of APP in agricultural workers to be as much as 18.2 per 100000 full time workers $^{3}$ and 7.4 per million among schoolchildren. ${ }^{4}$ Yet, cases of APP may be the result of various causes in different regions of the world. In developing countries, where there is insufficient regulation, lack of surveillance systems, less enforcement, lack of training, inadequate access to information systems, poorly maintained or nonexistent personal protective equipment, and larger agriculturally-based populations, the incidences are expected to be higher. ${ }^{5}$ The use of pesticides banned in industrialized countries, in particular, highly toxic pesticides as classified by $\mathrm{WHO},{ }^{6}$ obsolete stockpiles and improper storage techniques may provide unique risks in the developing world. ${ }^{7,8}$ In some countries, such as China and Sri Lanka, ${ }^{9}$ self-poisoning with pesticides is a particular problem. Studies from Sri Lanka regarding self poisoning reveal an APP incidence rate of approximately 180 per $100000 .^{10}$

Studies from developing areas in Central America (El Salvador and Nicaragua) have indicated an overall incidence rate of 35 per 100000 for
APP in the general population ${ }^{11}$ and 17.8 per 100000 occupationally-related APP in Thailand. ${ }^{12}$ In Belize, it has been estimated that 17 pesticide poisonings per 100000 residents and 4142 preventable poisonings occur each year. ${ }^{13}$ Previous research has demonstrated that reported occupational and nonintentional causes vary from $10 \%$ to $50 \%$ in developing countries. ${ }^{14}$ The reason for this variation is unclear, but is likely contributed to by inconsistent recording methodology and lack of a standard case definition for an APP. ${ }^{14}$ These variations may result in an underestimation of the true incidence of APP.

Since occupational and nonintentional pesticide poisoning require a specific set of prevention and control measures separate from those required for suicidal exposures, it is important to accurately determine the magnitude of the problem through better estimates and identification of cases and deaths resulting from APP. Several challenges

\footnotetext{
a Department of Emergency Medicine, Orlando Regional Medical Center, Orlando, FL, United States of America.

b Intergovernmental Forum on Chemical Safety (IFCS), World Health Organization, Geneva, Switzerland.

c European Centre for Environment and Health, WHO, Bonn, Germany.

d WHO, Geneva, Switzerland.

Correspondence to Josef G Thundiyil (e-mail: joseft@mindspring.com).
}

doi:10.2471/BLT.08.041814

(Submitted: 1 March 2007 - Revised version received: 20 July 2007 - Accepted: 11 September 2007 - Published online: 30 January 2008) 
exist in attempting to determine the scope of the problem: misdiagnosis by health-care providers, lack of readily accessible health care in rural populations, exclusion of non-hospitalized cases, resigned acceptance by workers that adverse health effects are expected, ${ }^{15}$ and the fact that less severe cases of APP may not seek health care. Additionally, suicidal ingestions of pesticides account for the most severe cases of poisoning and consequently hospital-based studies may underestimate the overall (occupational/non-intentional) incidence of APP. ${ }^{16}$ Further, many developing countries lack the resources to establish and maintain the necessary surveillance programmes and to obtain confirmatory laboratory testing for all possible cases of APP; therefore, the ability to identify a poisoning may differ between developing and developed countries. A standardized case definition will provide a practical tool for more accurately estimating the incidence of acute pesticide poisoning and identifying where problems exist to stimulate better management and control actions.

\section{Methods}

The work was conducted at the Intergovernmental Forum on Chemical Safety (IFCS) which is hosted by the WHO. The IFCS is a mechanism for cooperation among governments, intergovernmental organizations and nongovernmental organizations for promotion of chemical risk assessment and the environmentally sound management of chemicals. An extensive worldwide literature review was conducted to obtain all relevant materials regarding pesticidepoisoning surveillance, pesticide intoxication, pesticide-related exposures, definition of pesticide poisoning, and determination of incidence and prevalence of pesticide poisoning. The WHO Pesticide Project Surveillance Working Group (2001-2003) ${ }^{17}$ definition was used as a starting point. Additionally, all previous attempts to create a standardized definition of pesticide poisoning were obtained including those from the Environmental Protection Agency of the United States of America, the Pan American Health Organization, the Thai Food and Drug Administration, and the United States National Institute of Occupational Safety and Health.

These definitions were integrated into a single matrix definition which can be used across varying demographics, economies and settings. This initial definition matrix was sent to over thirty worldwide experts in the field of pesticide poisoning, pesticide surveillance, and members of industry on six different continents. The feedback was incorporated and the revised definition matrix was presented for further input to a workshop of health professionals from developing countries at the International Conference on Pesticide Use in Developing Countries in Arusha, United Republic of Tanzania, in October 2006. The case definition matrix presented here is the culmination of the review process.

\section{Challenges}

Classification strategies for APP must take into account the level of certainty of exposure, diversity of health effects, and plausibility that there is a causal link. Although, laboratory, biologic or environmental sampling may provide high specificity in detection of APP cases, sole reliance on these methods will result in a large proportion of missed cases. Further, while inpatient hospital records, suicide registries, forensic evidence and personal interviews may provide the strongest support for causation, these modes are too narrow and fail to provide adequate surveillance. Conversely, a case definition which is too broad may lack specificity and overestimate the true incidence of APP.

Due to the wide range of pesticides and their toxicities, clinical presentations can vary significantly. Additionally, it can be difficult to determine whether nonspecific symptoms are actually due to the pesticide exposure or other common environmental factors such as heat illness. Pesticides are defined as any substance or mixture of substances intended for preventing, destroying, repelling or mitigating any pest. ${ }^{8}$ Examples include herbicides, insecticides, rodenticides, fungicides, fumigants and wood treatment products. Pesticide exposure can occur via ingestion, inhalation, dermal absorption or ocular contact. It is important to identify whether signs and symptoms of pesticide poisoning are due to the active ingredient (the pesticide itself), inactive ingredients, solvents or additives which may vary by region, country, manufacturer or individual preference.
Table 1 (available at: http://www.who. int/bulletin/volumes/86/07/041814/ en/index.html) gives examples of pesticide classes and clinical presentations of possible adverse health effects resulting from unsafe exposure. The severity and likelihood of effects from APP can vary according to specific agent, dose, underlying physiologic reserve, comorbidities, route of exposure, organ system, age, poverty, ${ }^{18,19}$ education ${ }^{20}$ and other factors. Table 2 (available at: http://www.who.int/bulletin/ volumes/86/07/041814/en/index.html) provides a guideline for assessing severity of APP signs and symptoms.

\section{Case definition matrix for APP}

An acute pesticide poisoning is any illness or health effect resulting from suspected or confirmed exposure to a pesticide within 48 hours. Warfarins, superwarfarins and coumarins are an exception to this rule as the onset of laboratory findings or symptoms may be delayed greater than 48 hours. This includes APP resulting from suicide, homicide, occupational and nonintentional exposures. Health effects may be local (dermal and ocular) and/ or systemic. This includes respiratory, neurotoxic, cardiovascular, endocrine, gastrointestinal, nephrotoxic and allergic reactions. The definition of a case can be classified as: probable, possible or unlikely/unknown. ${ }^{11,21-24}$ These categories were chosen to provide simple delineations, ease of initial identification of cases and to provide a meaningful tool for quantifying the magnitude of problems in specific situations.

Table 3 presents the case definition matrix for APP proposed as a classification tool. The distinction between the "probable" and "possible" cases is arrived at by the requirement that the case meet one criteria in each of the categories (exposure, health effects and causality). A probable case refers to a case that is presumptive, substantiated or "more likely than not" caused by exposure to a pesticide. The "unlikely/ unknown" case definition represents cases for which there is unlikely or unknown causality or exposure. This category is arrived at by the requirement that the case meet only one criteria in any of the categories. Clinical evaluation, carried out by a health-care provider or trained personnel with some 
Table 3. Case definition matrix for acute pesticide poisoning

\begin{tabular}{|c|c|c|c|}
\hline Category & $\begin{array}{c}\text { Probable case } \\
\text { (meets at least one criterion in } \\
\text { each category) }\end{array}$ & $\begin{array}{c}\text { Possible case } \\
\text { (meets at least one criterion in } \\
\text { each category) }\end{array}$ & $\begin{array}{c}\text { Unlikely/unknown case } \\
\text { (meets at least one criterion } \\
\text { in any }{ }^{\mathrm{a}} \text { category) }\end{array}$ \\
\hline Exposure & $\begin{array}{l}\text { - Observation of pesticide residue, odour } \\
\text { or other contamination by a health-care } \\
\text { provider or trained personnel } \\
\text { - A plausible description of exposure based } \\
\text { on report by patient, witness or written } \\
\text { record of pesticides used } \\
\text { - Biological monitoring demonstrating } \\
\text { evidence of the pesticide in the body } \\
\text { (e.g. blood, serum, urine, sweat levels } \\
\text { of specific chemicals) or evidence of a } \\
\text { physiologic response to pesticide exposure } \\
\text { (e.g. depressed cholinesterase levels after } \\
\text { organophosphate exposure, prolonged } \\
\text { prothrombin time after coumarin exposure) } \\
\text { - Environmental sampling confirming } \\
\text { presence of the chemical in the soil, } \\
\text { clothing, air or water } \\
\text { - Clinical response to administration of } \\
\text { a treatment or antidote for pesticide } \\
\text { poisoning (e.g. atropine, vitamin K) }\end{array}$ & $\begin{array}{l}\text { - Observation of pesticide residue, odour } \\
\text { or other contamination by a health-care } \\
\text { provider or trained personnel } \\
\text { - A plausible description of exposure based } \\
\text { on report by patient, witness or written } \\
\text { record of pesticides used } \\
\text { - Biological monitoring suggesting presence } \\
\text { (but not excess) of the pesticide in the body } \\
\text { (e.g. blood, serum, urine, sweat levels of } \\
\text { specific chemicals) } \\
\text { - Environmental sampling confirming } \\
\text { presence of the chemical in the soil, } \\
\text { clothing, air or water }\end{array}$ & $\begin{array}{l}\text { - No evidence of exposure } \\
\text { - Evidence of no exposure }\end{array}$ \\
\hline Health effects & $\begin{array}{l}\text { Documentation by a health-care provider or } \\
\text { trained personnel of: } \\
\text { - a characteristic toxidrome or health effect } \\
\text { from the pesticide } \\
\text { - a physical sign }{ }^{\mathrm{b}} \text { consistent with pesticide } \\
\text { exposure and not easily explained by } \\
\text { another condition } \\
\text { - a laboratory test consistent with pesticide } \\
\text { exposure and not easily explained by } \\
\text { another condition } \\
\text { - three or more symptoms }{ }^{\mathrm{b}} \text { (not verifiable by } \\
\text { objective means) compatible with pesticide } \\
\text { exposure }\end{array}$ & $\begin{array}{l}\text { Documentation by a health-care provider or } \\
\text { trained personnel of: } \\
\text { - a health effect from the pesticide exposure } \\
\text { even in the absence of a specific toxidrome } \\
\text { - an exacerbation of a pre-existing illness } \\
\text { (e.g. triggering asthma) } \\
\text { - two or more subjective symptoms reported } \\
\text { by the patient without objective evidence of } \\
\text { physical findings or laboratory evidence }\end{array}$ & $\begin{array}{l}\text { - No documented signs or } \\
\text { symptoms: }{ }^{\text {b }} \\
\text { - only one subjective } \\
\text { symptom }^{\text {b }} \text { (not verifiable by } \\
\text { objective means) } \\
\text { - insufficient information on } \\
\text { health effects }\end{array}$ \\
\hline Causality & $\begin{array}{l}\text { - Temporal cause-effect relationship between } \\
\text { exposure and health effect consistent with } \\
\text { the known toxicology of the pesticide }\end{array}$ & $\begin{array}{l}\text { - Temporal cause-effect relationship between } \\
\text { exposure and health effect consistent with } \\
\text { the known toxicology of the pesticide } \\
\text { - Temporal cause-effect relationship between } \\
\text { exposure and health effect(s) consistent } \\
\text { with published case reports of the health } \\
\text { effects of the pesticide } \\
\text { - Temporal relationship between exposure } \\
\text { and health effect(s) that have not yet been } \\
\text { observed provided there is no other likely } \\
\text { explanation for the effects and the effects } \\
\text { do not contradict present knowledge of the } \\
\text { toxicology of the pesticide }\end{array}$ & $\begin{array}{l}\text { - Implausible temporal } \\
\text { cause-effect relationship } \\
\text { between exposure and } \\
\text { health effects } \\
\text { - Health effects are not } \\
\text { consistent with known } \\
\text { toxicology or case reports of } \\
\text { the pesticide } \\
\text { - Insufficient causality } \\
\text { information }\end{array}$ \\
\hline
\end{tabular}

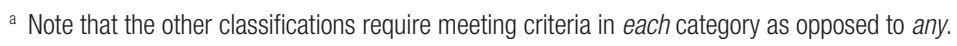

${ }^{b}$ A distinction is to be made between signs and symptoms. A physical sign is an objective finding that can be described by a health-care provider or trained personnel (e.g. diaphoresis, tachycardia, vomiting). A symptom is a subjective complaint reported by a patient (e.g. nausea, headache, dizziness).

knowledge of the health effects caused by exposure to pesticides, is advised when making a determination about health effects. A distinction is to be made between signs and symptoms. A physical sign is an objective finding that can be described by a health-care provider (e.g. diaphoresis, tachycardia, vomiting). A symptom is a subjective complaint reported by a patient (e.g. nausea, headache, dizziness). The information in Table 1 and Table 2 provides guidance for the determination of health effects. It is important to keep in mind that since all the possible toxic effects of each pesticide are not entirely known, the possibility may still exist that certain symptoms represent new, as yet undocumented, health effects from a pesticide.

\section{Discussion}

This paper provides a standard definition and classification scheme for APP to enable its identification and diagnosis, especially at the field level, 
rural clinics, and primary health-care systems. The case matrix definition is a synthesis of existing case definitions that have been previously proposed by other authors. ${ }^{12,13,21-24}$ The lack of a standardized definition and classification scheme has hindered identification and quantification of APP cases which in many situations results in a failure to establish adequate prevention and control measures. ${ }^{16}$

It is intended to provide a case definition for acute pesticide poisoning and consequently does not account for chronic effects (e.g. carcinogenesis, neurological effects, reproductive effects and developmental abnormalities). While these potential effects have significant public health importance, the scope of this definition does not allow for assessment of chronic poisoning.

The case definition is designed to account for the wide range of clinical practice, methods of diagnosis and observational epidemiological/surveillance methods that exist across the world.
Such information collected can substantively contribute to identification of existing problems and thus promote action for improved management and prevention. ${ }^{21}$ Based on the proposed criteria, laboratory confirmation is not absolutely necessary to meet the standard of a probable APP. Notwithstanding, thorough clinical evaluation, carried out by a health-care provider or trained personnel with some knowledge of the health effects caused by unsafe exposure to pesticides, is required. Hospitalization is not a precondition for using the case definition to classify an incident.

Finally, due to the complexity of this public health problem, the use of this definition has its limitations. Many individuals and workers who experience health effects from APP may never present to a health-care provider due to distance from a medical facility, lack of resources, economic factors, fear of job loss or other reasons..$^{25,26}$ Some healthcare providers may be unaware of the relationship between pesticide and illnesses and fail to diagnose or report the incident properly. Additionally, some pesticides may not be properly mixed, prepared, applied, labelled or registered, ${ }^{27-29}$ making the determination of the agent of exposure difficult. Although this definition provides a framework for further epidemiologic study, it does not serve as a substitute for a national registry of pesticide use and illness. By enabling a field identification of APP, this standardized case definition may facilitate immediate medical management of pesticide poisoning and aid in estimating its incidence. As this case definition is used in different countries and situations, it will be kept under review and updated on the basis of lessons learned. The information provided from its use will provide guidance for future research projects and the implementation of exposure prevention and management programmes.

Competing interests: None declared.

\section{Résumé}

\section{Intoxication aiguë par les pesticides : proposition d'un outil de classification}

Les cas d'intoxication aiguë par un pesticide (IAP) représentent une morbidité et une mortalité conséquentes dans l'ensemble du monde. Les pays en développement sont particulièrement vulnérables en raison d'un manque de réglementation, de systèmes de surveillance, d'application des règles et de formation et d'une insuffisance de l'accès aux systèmes d'information. Des études antérieures ont mis en évidence une grande variabilité des taux d'incidence de ces intoxications aiguës. II est possible que cette variabilité résulte d'un manque de consistance dans la méthodologie de notification et de l'exclusion des intoxications professionnelles et involontaires. L'objectif de ce document est d'élaborer une définition de cas standard pour faciliter l'identification et le diagnostic de toutes les causes d'IAP, notamment sur le terrain, dans les dispensaires ruraux et dans le cadre des systèmes de soins de santé primaire. II présente une synthèse de la littérature existante et des définitions de cas déjà proposées par d'autres auteurs de part le monde. II propose également une définition de cas standardisée et un schéma de classification des IAP en catégories de cas :, potentiels ou improbables/indéterminés. L'une et l'autre sont destinés à être appliqués dans le monde entier pour faciliter l'évaluation de l'ampleur des problèmes existants et promouvoir des actions pour améliorer la prise en charge et la prévention. En permettant un diagnostic sur le terrain des IAP, cette définition de cas standardisée peut faciliter une prise en charge médicale immédiate des intoxications et aider à estimer leur incidence.

\section{Resumen}

Intoxicación aguda por plaguicidas: propuesta de instrumento de clasificación

Los casos de intoxicación aguda por plaguicidas (IAP) son una causa importante de morbilidad y mortalidad a nivel mundial. Los países en desarrollo son particularmente vulnerables, pues en ellos coinciden una escasa regulación de esos productos, la falta de sistemas de vigilancia, un menor cumplimiento de las normas y un acceso insuficiente a los sistemas de información. Investigaciones anteriores han puesto de relieve una gran variabilidad de las tasas de incidencia de IAP. Ello se debe posiblemente a unos métodos de notificación incongruentes y a la exclusión de las intoxicaciones laborales y no intencionales. La finalidad de este artículo es crear una definición de caso estándar que facilite la identificación y el diagnóstico de todas las causas de IAP, especialmente sobre el

primaria. Se hace una síntesis de la bibliografía existente y de las definiciones de caso propuestas anteriormente por otros autores en todo el mundo, y se proporciona una definición de caso normalizada y un sistema de clasificación de las IAP en tres categorías: probable, posible e improbable/origen desconocido. Esos criterios se han concebido de manera que puedan aplicarse en todo el mundo para facilitar la determinación de la magnitud de los problemas existentes y promover así la adopción de medidas que mejoren el tratamiento y la prevención. Posibilitando el diagnóstico sobre el terreno de las IAP, esa definición de caso normalizada puede facilitar el tratamiento médico inmediato de la intoxicación por plaguicidas y la estimación de su incidencia.
} terreno, en los consultorios rurales y en los centros de atención 


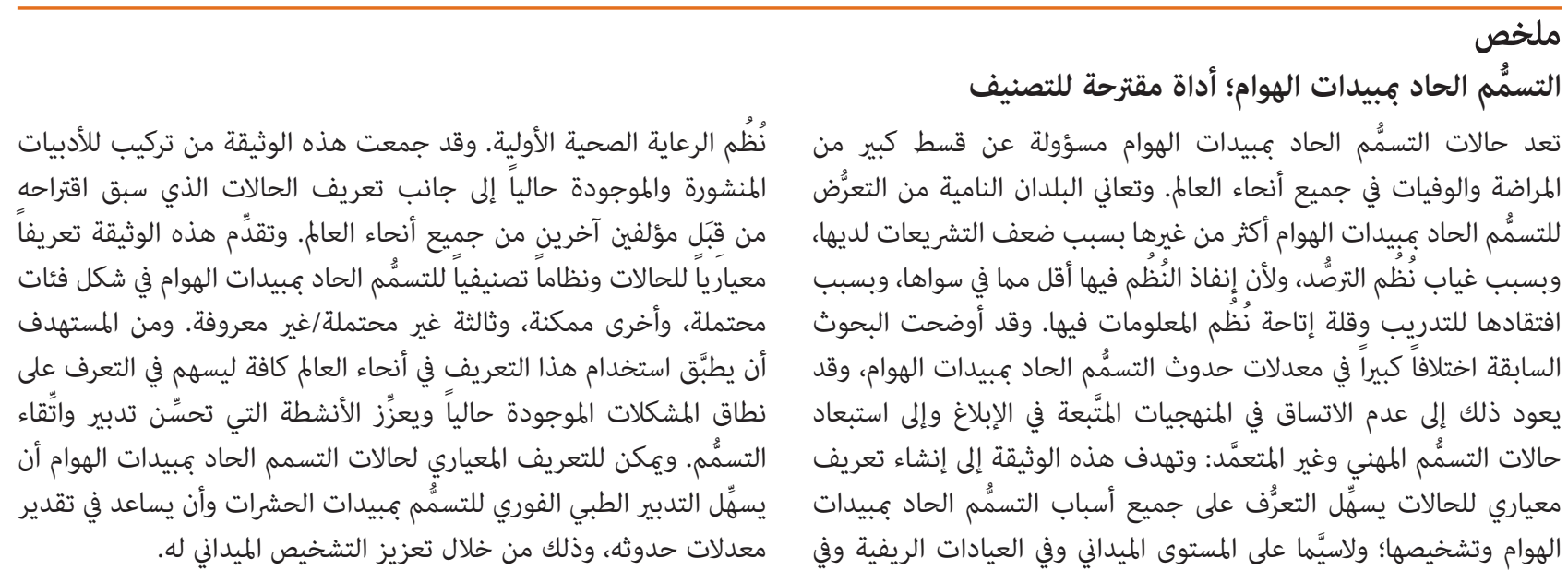

\section{References}

1. Kishi M, Ladou J. International pesticide use. Int J Occup Environ Health 2001;7:259-65. PMID:11783855

2. Jeyaratnam J. Acute pesticide poisoning: a major global health problem. World Health Stat Q 1990;43:139-44. PMID:2238694

3. Calvert GM, Plate DK, Das R, Rosales R, Shafey O, Thomsen C, et al. Acute occupational pesticide-related illness in the US, 1998-1999: surveillance findings from the SENSOR-pesticides program. Am J Ind Med 2004;45:14-23. PMID:14691965 doi:10.1002/ajim.10309

4. Alarcon WA, Calvert GM, Blondell JM, Mehler LN, Sievert J, Propeck M, et al. Acute illnesses associated with pesticide exposure at school. JAMA 2005; 294:455-65. PMID:16046652 doi:10.1001/jama.294.4.455

5. Acutely toxic pesticides: initial input on extent of problem and guidance for risk management. Fourth session of the Intergovernmental Forum on Chemical Safety. Doc number: IFCS/FORUM-IV/10w; April 2003.

6. Recommended classification of pesticides by hazard, and guidelines to classification. Geneva: WHO; 2006.

7. McConnell R, Hruska AJ. An epidemic of pesticide poisoning in Nicaragua: implications for prevention in developing countries. Am J Public Health 1993:83:1559-62. PMID:8238678

8. International code of conduct on the distribution and use of pesticides. Rome: Food and Agriculture Organization of the United Nations; 2003.

9. Chen SY, Zhou J, Li ZJ, Wu YQ. A survey of emergency treatment of pesticides poisoning in comprehensive hospitals. Zhonghua Lao Dong Wei Sheng Zhi Ye Bing Za Zhi 2004;22:364-7. PMID:15555314

10. Eddleston M, Sudarshan K, Senthilkumaran M, Reginald K, Karalliedde L, Senarathna $L$, et al. Patterns of hospital transfer for self-poisoned patients in rural Sri Lanka: implications for estimating the incidence of self-poisoning in the developing world. Bull World Health Organ 2006;84:276-82. PMID:16628300 doi:10.2471/BLT.05.025379

11. Henao S, Arbelaez MP. Epidemiological situation of acute pesticide poisoning in the Central American Isthmus, 1992-2000. Pan American Health Organization (PAHO) PLAGSALUD. Epidemiol Bull 2002;23:5-9. PMID:12608345

12. Establishment of pesticide poisoning database on human pesticide exposure: internal report. Thai Food and Drug Administration, Nakorn-Pathom Provincial Health Office; 2003.

13. Osorio AM, Maza R, Panagos H, Maibach H. Evaluation of chemical exposures among papaya industry workers in Belize: final report. International conference on pesticide exposure and health, 8-12 July 2002, Bethesda, MA. Society for Occupational and Environmental Health.

14. Epidemiology of pesticide poisoning: harmonized collection of data on human pesticide exposure in selected countries. Geneva: International Programme on Chemical Safety/WHO; 2004.

15. Alavanja MC, Sprince NL, Oliver E, Whitten P, Lynch CF, Gillette PP, et al. Nested case control analysis of high pesticide exposure events from the agricultural health study. Am J Ind Med 2001;39:557-63. PMID:11385639 doi:10.1002/ajim.1054

16. Litchfield MH. Estimates of acute pesticide poisoning in agricultural workers in less developed countries. Toxicol Rev 2005;24:271-8. PMID:16499408 doi:10.2165/00139709-200524040-00006

17. Report of. The first pesticide surveillance group meeting, WHO Pesticide Project Surveillance Working Group (internal report), Washington, 5-6 July 2002. Geneva: WHO, 2002.

18. Mancini F, Van Bruggen AH, Jiggins JL, Ambatipudi AC, Murphy H. Acute pesticide poisoning among female and male cotton growers in India. Int $J$ Occup Environ Health 2005;11:221-32. PMID:16130962

19. Tinoco-Ojanguren R, Halperin DC. Poverty, production and health: inhibition of erythrocyte cholinesterase via occupational exposure to organophosphate insecticides in Chiapas. Mexico Arch Environ Health 1998;53:29-35.

20. Oliveira-Silva JJ, Alves SR, Meyer A, Perez F, Sarcinelli PN, da Costa Mattos RC, et al. Influence of social-economic factors on the pesticide poisoning, Brazil. Rev Saude Publica 2001;35:130-5. PMID:11359198

21. Henao S, Arbalaez M. Epidemiological surveillance system for acute pesticide poisoning. Epidemiol Bull 2001;22:4-11.

22. Keifer M, McConnell R, Pacheco AF, Daniel W, Rosenstock L. Estimating underreported pesticide poisoning in Nicaragua. Am J Ind Med 1996; 30:195-201. PMID:8844049 doi:10.1002/(SICI)10970274(199608)30:2<195::AID-AJIM10>3.0.C0;2-S

23. Reeves M, Schafer KS. Greater risks, fewer rights: US farmworkers and pesticides. Int J Occup Environ Health 2003;9:30-9. PMID:12749629

24. Meulenbelt J, de Vries I. Acute work-related poisoning by pesticide in the Netherlands; a one year follow up study. Przegl Lek 1997;54:665-70. PMID:9478083

25. Damalas CA, Georgiou EB, Theodorou MG. Pesticide use and safety practices among Greek tobacco farmers: a survey. Int $J$ Environ Health Res 2006:16:339-48. PMID:16990175 doi:10.1080/09603120600869190

26. Sivayoganathan C, Gnanachandran S, Lewis J, Fernando M. Protective measure use and symptoms among agropesticide applicators in Sri Lanka. Soc Sci Med 1995;40:431-6. PMID:7725116 doi:10.1016/02779536(94)00143-H

27. Barnett M, Calvert GM. Pesticide-related illness and injury surveillance: a how to guide for state-based programs. Publication number 2006-102. Department of Health and Human Services, Centers for Disease Control and Prevention, National Institute for Occupational Safety and Health; 2005.

28. Pesticide Poisoning. Investigative Guidelines. Oregon Health Division; 1995. Available from: http://www.oregon.gov/DHS/ph/acd/reporting/guideln/ pesticid.pdf

29. Reigart JR, Roberts JR. Recognition and management of pesticide poisoning, 5th edn. United States Environmental Protection Agency; 1999. Available from: http://www.epa.gov/oppfead1/safety/healthcare/handbook/Front.pdf

30. Persson HE, Sjöberg GK, Haines JA, Pronczuk de Garbino J. Poisoning severity score: grading of acute poisoning. J Toxicol Clin Toxicol 1998;36:205-13. PMID:9656975 
Table 1. Adverse health effects caused by selected classes of pesticides ${ }^{\text {a }}$

\begin{tabular}{|c|c|c|c|}
\hline Chemical/chemical class & Examples of pesticides & Clinical presentation & $\begin{array}{l}\text { Route of } \\
\text { exposure }\end{array}$ \\
\hline Arsenicals & $\begin{array}{l}\text { Arsenic trioxide, CCA, sodium } \\
\text { arsenate }\end{array}$ & $\begin{array}{l}\text { Abdominal pain, nausea, vomiting, garlic odour, } \\
\text { metallic taste, bloody diarrhoea, headache, dizziness, } \\
\text { drowsiness, weakness, lethargy, delirium, shock, kidney } \\
\text { insufficiency, neuropathy }\end{array}$ & $\begin{array}{l}0, \mathrm{R}, \mathrm{D} \\
\text { (rarely) }\end{array}$ \\
\hline Borates (insecticide) & Boric acid, borax & $\begin{array}{l}\text { Upper airway irritation, abdominal pain, nausea, } \\
\text { vomiting, diarrhoea, headache, lethargy, tremor, kidney } \\
\text { insufficiency }\end{array}$ & $\begin{array}{l}\text { 0, R, D } \\
\text { (broken skin) }\end{array}$ \\
\hline Carbamates (insecticide) & $\begin{array}{l}\text { Carbaryl, thiram, aldicarb, } \\
\text { mecarbam }\end{array}$ & $\begin{array}{l}\text { Malaise, weakness, dizziness, sweating, headache, } \\
\text { salivation, nausea, vomiting, diarrhoea, abdominal pain, } \\
\text { confusion, dyspnea, dermatitis, pulmonary oedema }\end{array}$ & $0, D$ \\
\hline $\begin{array}{l}\text { Chlorphenoxy compounds } \\
\text { (herbicides) }\end{array}$ & $\begin{array}{l}\text { Di/tri- chlorophenoxyacetic } \\
\text { acid, MCPP }\end{array}$ & $\begin{array}{l}\text { Upper airway and mucous membrane irritation, } \\
\text { abdominal pain vomiting, diarrhoea, tachycardia, } \\
\text { weakness, muscle spasm, coma, acidosis, hypotension, } \\
\text { ataxia, hypertonia, seizures, dermal irritation, headache, } \\
\text { confusion, acidosis, tachycardia }\end{array}$ & $0, \mathrm{D}$ \\
\hline Calciferol (rodenticide) & Cholecalciferol, ergocalciferol & $\begin{array}{l}\text { Fatigue, anorexia, weakness, headache, nausea, } \\
\text { polyuria, polydipsia, renal injury, hypercalcemia }\end{array}$ & 0 \\
\hline Chloralose & Chloralose & $\begin{array}{l}\text { Vomiting, vertigo, tremor, myoclonus, fasciculations, } \\
\text { confusion, convulsions }\end{array}$ & 0 \\
\hline Copper compounds (fungicide) & Copper acetate, copper oleate & $\begin{array}{l}\text { Abdominal pain, vomiting, skin/airway/mucous } \\
\text { membrane irritation, renal dysfunction, coma }\end{array}$ & $0, R, D$ \\
\hline Coumarins (rodenticide) & $\begin{array}{l}\text { Brodifacoum, warfarin, } \\
\text { pindone }\end{array}$ & $\begin{array}{l}\text { Echymoses, epistaxis, excessive bleeding, haematuria, } \\
\text { prolonged prothrombin time, intracranial bleed, anaemia, } \\
\text { fatigue, dyspnea }\end{array}$ & $\begin{array}{c}0, \mathrm{D} \\
\text { (possible) }\end{array}$ \\
\hline $\begin{array}{l}\text { Diethyltoluamide (insect } \\
\text { repellent) }\end{array}$ & $\begin{array}{l}\text { DEET (N,N-diethyl-meta- } \\
\text { toluamide) }\end{array}$ & $\begin{array}{l}\text { Dermatitis, ocular irritation, headache, restlessness, } \\
\text { ataxia, confusion, seizures, urticaria }\end{array}$ & $0, \mathrm{D}$ \\
\hline Dipyridil (herbicide) & Paraquat, diquat & $\begin{array}{l}\text { Mucous membrane and airway irritation, abdominal } \\
\text { pain, diarrhoea, vomiting, gastrointestinal bleeding, } \\
\text { pulmonary oedema, dermatitis, renal and hepatic } \\
\text { damage, coma, seizures }\end{array}$ & $\begin{array}{c}\text { O, D } \\
\text { (via broken skin) }\end{array}$ \\
\hline Phosphonates (herbicide) & Roundup, glyphosate & $\begin{array}{l}\text { Airway, skin, and mucous membrane irritation, } \\
\text { abdominal, pain, nausea, vomiting, shock, dyspnea, } \\
\text { respiratory failure }\end{array}$ & $0, R$ \\
\hline Fluoroacetate (rodenticide) & Sodium fluoroacetate & $\begin{array}{l}\text { Vomiting, paresthesias, tremors, seizures, hallucinations, } \\
\text { coma, confusion, arrhythmias, hypertension, cardiac } \\
\text { failure }\end{array}$ & $\begin{array}{c}0, \mathrm{D} \\
\text { (possible) }\end{array}$ \\
\hline Mercury, organic (fungicide) & Methyl mercury & $\begin{array}{l}\text { Metallic taste, paresthesias, tremor, headache, } \\
\text { weakness, delirium, ataxia, visual changes, dermatitis, } \\
\text { renal dysfunction }\end{array}$ & $0, R, D$ \\
\hline $\begin{array}{l}\text { Metal phosphides } \\
\text { (rodenticide, fumigant) }\end{array}$ & $\begin{array}{l}\text { Zinc-, aluminium-, } \\
\text { magnesium- phosphide }\end{array}$ & $\begin{array}{l}\text { Abdominal pain, diarrhoea, acidosis, shock, jaundice, } \\
\text { paresthesias, ataxia, tremors, coma, pulmonary oedema, } \\
\text { tetany, dermal irritation }\end{array}$ & $0, R, D$ \\
\hline Halocarbons (fumigant) & Cellfume, Methyl bromide & $\begin{array}{l}\text { Skin/airway/mucous membrane irritant, cough, renal } \\
\text { dysfunction, confusion, seizures, coma, pulmonary } \\
\text { oedema }\end{array}$ & $0, R, D$ \\
\hline $\begin{array}{l}\text { Nitrophenolic and nitrocresolic } \\
\text { herbicides }\end{array}$ & $\begin{array}{l}\text { Dinitrophenol, dinitrocresol, } \\
\text { dinoseb, dinosarn }\end{array}$ & $\begin{array}{l}\text { Sweating, fever, confusion, malaise, restlessness, } \\
\text { tachycardia, yellow skin staining, seizures, coma, renal } \\
\text { insufficiency, hepatic damage }\end{array}$ & $0, R, D$ \\
\hline Organochlorines (insecticide) & $\begin{array}{l}\text { Aldrin, dieldrin HCB, endrin, } \\
\text { lindane }\end{array}$ & $\begin{array}{l}\text { Cyanosis, excitability, dizziness, headache, restlessness, } \\
\text { tremors, convulsions, coma, paresthesias, nausea, } \\
\text { vomiting, confusion, tremor, cardiac arrhythmias, } \\
\text { acidosis }\end{array}$ & $0, R, D$ \\
\hline
\end{tabular}


(Table 1, cont.)

\begin{tabular}{|c|c|c|c|}
\hline Chemical/chemical class & Examples of pesticides & Clinical presentation & $\begin{array}{l}\text { Route of } \\
\text { exposure }^{b}\end{array}$ \\
\hline $\begin{array}{l}\text { Organophosphates } \\
\text { (insecticides) }\end{array}$ & $\begin{array}{l}\text { Malathion, parathion, } \\
\text { dichlorvos, chlorpyrifos }\end{array}$ & $\begin{array}{l}\text { Headache, dizziness, bradycardia, weakness, anxiety, } \\
\text { excessive sweating, fasciculations, vomiting, diarrhoea, } \\
\text { abdominal cramps, dyspnea, miosis, paralysis, } \\
\text { salivation, tearing, ataxia, pulmonary oedema, confusion, } \\
\text { acetylcholinesterase inhibition }\end{array}$ & $0, D$ \\
\hline Organotin (fungicide) & Fentin acetate, fentin chloride & $\begin{array}{l}\text { Airway, skin, and mucous membrane irritation, } \\
\text { dermatitis, salivation, delirium, headache, vomiting, } \\
\text { dizziness }\end{array}$ & $0, R, D$ \\
\hline $\begin{array}{l}\text { Phenol derivatives (Fungicide, } \\
\text { wood preservative) }\end{array}$ & $\begin{array}{l}\text { Pentachlorophenol, } \\
\text { dinitrophenol }\end{array}$ & $\begin{array}{l}\text { Skin, airway, and mucous membrane irritation, contact } \\
\text { dermatitis, dyspnea, diaphoreses, urticaria, tachycardia, } \\
\text { headache, abdominal pain, fever, tremor }\end{array}$ & $0, R, D$ \\
\hline Pyrethrins, Pyrethroids & $\begin{array}{l}\text { Allethrin, cyfluthrin, } \\
\text { permethrin }\end{array}$ & $\begin{array}{l}\text { Allergic reactions, anaphylaxis, dermatitis, paresthesias, } \\
\text { wheezing, seizures, coma, pulmonary oedema, } \\
\text { diarrhoea, abdominal pain }\end{array}$ & $R, D$ \\
\hline Strychnine (rodenticide) & Strychnine & Muscle rigidity, opisthotonus, rhabdomyolysis & 0 \\
\hline Thallium (rodenticide) & Thallium sulfate & $\begin{array}{l}\text { Abdominal pain, nausea, vomiting, bloody diarrhoea, } \\
\text { headache, weakness, liver injury, hair loss, paresthesias, } \\
\text { neuropathy, encephalopathy, cardiac failure }\end{array}$ & 0 \\
\hline Triazines (herbicide) & Atrazine, prometryn & Mucous membrane, ocular and dermal irritation & $0, R, D$ \\
\hline
\end{tabular}

CCA, chromated copper arsenate; HCB, hexachlorobenzene; MCPP, methyl chlorphenoxy propionic acid.

a This list is an overview and is not meant to be a comprehensive list of all pesticide and pesticide classes. The health worker is encouraged to use other resources and clinical experience in establishing health effect and causality for acute pesticide poisoning. Suggested online references include: http://www.who.int/whopes/ recommendations/PCSPesticide_ok.pdf, http://npic.orst.edu/npicfact.htm, http://www.epa.gov/pesticides/safety/healthcare/handbook/handbook.pdf, http://www. cdc.gov/niosh/topics/pesticides/pdfs/pest-cd2app2v2.pdf, http://hazard.com/msds/, http://www.epa.gov/pesticides/reregistration/status.htm, http://pesticideinfo. org/, http://toxnet.nIm.nih.gov/cgi-bin/sis/htmlgen?HSDB, http://www.pesticideinfo.org/Search_Countries.jsp.

${ }^{b}$ Route of exposure key: 0 , oral/ingestion; R, respiratory/inhalation; D, dermal or ocular.

Based on references 22-24. 
Table 2. Signs and symptoms by organ system and severity category

\begin{tabular}{|c|c|c|c|c|}
\hline \multirow[t]{2}{*}{ Organ system } & \multicolumn{4}{|c|}{ Severity of symptoms } \\
\hline & Fatal & High & Moderate & Low \\
\hline Gastrointestinal & Death & $\begin{array}{l}\text { Massive haemorrhage } \\
\text { Gut perforation } \\
\text { 2nd or 3rd degree burns } \\
\text { Severe dysphagia }\end{array}$ & $\begin{array}{l}\text { Diarrhoea } \\
\text { Vomiting } \\
\text { Bloody stools } \\
\text { Jaundice }\end{array}$ & $\begin{array}{l}\text { Abdominal cramping } \\
\text { Loss of appetite } \\
\text { Nausea } \\
\text { Oral irritation } \\
\text { Constipation }\end{array}$ \\
\hline Respiratory & Death & $\begin{array}{l}\text { Cyanosis and respiratory depression } \\
\text { Pulmonary oedema } \\
\text { Respiratory arrest }\end{array}$ & $\begin{array}{l}\text { Diffuse radiographic abnormalities } \\
\text { Pleuritic chest pain } \\
\text { Respiratory depression } \\
\text { Bronchospasm } \\
\text { Dyspnoea }\end{array}$ & $\begin{array}{l}\text { Cough } \\
\text { Airway irritation } \\
\text { Rhinitis } \\
\text { Sneezing }\end{array}$ \\
\hline Nervous & Death & $\begin{array}{l}\text { Coma } \\
\text { Paralysis } \\
\text { Seizure } \\
\text { Stupor } \\
\text { Widespread neurologic impairment }\end{array}$ & $\begin{array}{l}\text { Confusion } \\
\text { Hallucinations } \\
\text { Blurred vision } \\
\text { Ataxia } \\
\text { Slurred speech } \\
\text { Syncope } \\
\text { Hearing loss } \\
\text { Localized neuropathy/ paraesthesias }\end{array}$ & $\begin{array}{l}\text { Hyperactivity } \\
\text { Headache } \\
\text { Profuse sweating } \\
\text { Dizziness } \\
\text { Tremor } \\
\text { Tinnitus } \\
\text { Drowsiness }\end{array}$ \\
\hline Cardiovascular & Death & $\begin{array}{l}\text { Bradycardia: HR }<40 \text { adults, }<60 \text { children, } \\
<80 \text { neonates } \\
\text { Tachycardia: HR > } 180 \text { adults, }>190 \\
\text { children, }>200 \text { neonates } \\
\text { Cardiac arrest } \\
\text { Myocardial infarction } \\
\text { Shock }\end{array}$ & $\begin{array}{l}\text { Bradycardia: HR 40-50 adults, } \\
60-80 \text { children, 80-90 neonates } \\
\text { Tachycardia: HR 140-180 adults, } \\
\text { 160-190 children, 160-200 neonates } \\
\text { Chest pain } \\
\text { Conduction disturbance } \\
\text { Hypertension } \\
\text { Hypotension }\end{array}$ & $\begin{array}{l}\text { Isolated extrasystoles } \\
\text { Mild transient } \\
\text { hypertension }\end{array}$ \\
\hline Metabolism & Death & $\begin{array}{l}\text { Acid/base disturbance }(\mathrm{pH}<7.15 \text { or }>7.7) \\
\text { Severe electrolyte imbalance }\end{array}$ & $\begin{array}{l}\text { Elevated anion gap } \\
\text { Acidosis (pH 7.15-7.30) } \\
\text { Alkalosis (pH 7.60-7.69) }\end{array}$ & $\begin{array}{l}\text { Fever of short duration } \\
\text { Mild hyperglycaemia }\end{array}$ \\
\hline Renal & Death & $\begin{array}{l}\text { Anuria } \\
\text { Renal failure }\end{array}$ & $\begin{array}{l}\text { Haematuria } \\
\text { Oliguria } \\
\text { Proteinuria }\end{array}$ & Polyuria \\
\hline Muscular & Death & $\begin{array}{l}\text { Muscle rigidity and rhabdomyolysis } \\
\text { Compartment syndrome }\end{array}$ & $\begin{array}{l}\text { Fasciculations } \\
\text { Rigidity } \\
\text { Weakness }\end{array}$ & $\begin{array}{l}\text { Muscle weakness } \\
\text { Muscle pain }\end{array}$ \\
\hline Dermatologic & Death & $\begin{array}{l}\text { Burns: } 2 \text { nd degree }>50 \% \text { total BSA } \\
\text { Burns: } 3 \text { rd degree of }>2 \% \text { BSA }\end{array}$ & $\begin{array}{l}\text { Bullae } \\
\text { Burns: 2nd degree }<50 \% \text { BSA } \\
\text { Burns: 3rd degree of }<2 \% \text { BSA }\end{array}$ & $\begin{array}{l}\text { Oedema, swelling, } \\
\text { Erythema, irritation } \\
\text { Urticaria }\end{array}$ \\
\hline Ocular & Death & $\begin{array}{l}\text { Corneal ulcer } \\
\text { Corneal perforation } \\
\text { Loss of vision }\end{array}$ & $\begin{array}{l}\text { Corneal abrasion } \\
\text { Ocular burn } \\
\text { Visual changes }\end{array}$ & $\begin{array}{l}\text { Lacrimation } \\
\text { Mydriasis } \\
\text { Miosis } \\
\text { Pain/ conjunctivitis }\end{array}$ \\
\hline Other & Death & - & - & $\begin{array}{l}\text { Fatigue } \\
\text { Malaise }\end{array}$ \\
\hline
\end{tabular}

BSA, body surface area; HR, heart rate.

Based on references 22 and 30. 